particularly is the inevitable fact that, in a comprehensive work of this character, sections are liable to become out of date owing to later work while the book is in the press; and most of the faults that one might find would be of this nature.

Prof. Nölke gives a thoughtful account of theories of the origin of the solar system, but does not appear to have grasped the essential difficulty of explaining how the comparatively small masses of the planets succeeded in holding themselves together for a long enough time to be able to condense. In places also he seems to have misunderstood the work of other investigators. Berg, writing on geochemistry, supports the eclogite-sulphide constitution of the rocky shell, but Gutenberg himself seems to agree with the reviewer that the evidence is in favour of dunite. Other chapters deal with the figure of the earth, its age, geological history, thermal history, igneous activity, movements of the crust, effects of ice, and geophysical prospecting.

Special mention may be made of Gutenberg's theory of continental spreading. He admits the force of the mechanical objections to continental drift as usually understood, but notices that the weight of continents implies shearing stresses within them of the order of magnitude of the strength, and consequently supposes that they may have spread out under their own weight. H. J.

\section{Business and Science: being Collected Papers read to the Department of Industrial Co-operation at the Centenary Meeting of the British Association for the Advancement of Science, London, September 1931. Edited by R. J. Mackay. Published by Authority of the Council of the British Associa- tion for the Council of the Management Research Groups of Great Britain. Pp. xvi +312 . (Lon- don : The Sylvan Press (Henderson and Spalding, Ltd.), 1932.) $5 s$.}

THE various papers collected in this volume form a valuable contribution to the study of problems of management. Mr. B. Seebohm Rowntree points out in a foreword that good management is the most important and most dependable factor in the prosperity of a business. He emphasises that business management is a complicated science which must be studied as laboriously as one studies chemistry, medicine, or engineering, and on the extent to which individual employers succeed in mastering that science will depend not only the prosperity of their own firms but also that of the nation to which they belong.

The field covered by the papers is very wide, and includes contributions from some forty speakers, grouped into five sections, entitled "The Study of Management", "Preparation for Management", "Body and Mind at Work", "Some Higher Management Problems", and "The Development of Invention". In the section "Preparation for Management" an interesting account is given of various educational institutions which aim at providing training for the higher administrative posts in industry. Viscount Leverhulme describes the Staff Training College and the "Trainee System" of Messrs. Lever Brothers ; M. Pierre Jolly explains the methods adopted at the Business Preparation Centre recently inaugurated by the Paris Chamber of Commerce, of which a special feature has been the establishment of a bureau to collect and prepare materials drawn from actual business problems to be used as ' cases' for demonstrating to students the application of theoretical principles to practice ; Dr. Bowie details the methods adopted in the College of Technology, Manchester, where the first Depart. ment of Industrial Administration was established in Great Britain; Prof. Florence describes the commerce course of the University of Birmingham, while Prof. McNair tells of the work carried out at the Graduate School of Business Administration, Harvard University.

Sexual Life in Ancient Greece. By Hans Licht. Translated by J. H. Freese. Edited by L. H. Dawson. Pp. XV $+557+32$ plates. (London: George Routledge and Sons, Ltd., 1932.) 42s.net.

THe late Dr. Licht's study of the sexual life of the Greeks of antiquity is a marvel of erudition. $\mathrm{He}$ ransacked Greek literature from end to end-from Homer to the latest writers in the Greek tradition of the beginning of the Middle Ages-and there is no side of eroticism to which any reference is made that he did not bring under review. The attitude of the Greeks towards the human body, their clothing, their marriages, the place of sex in festivals and games, in the theatre, and in religion are demonstrated by reference to, or quotation from, their own statements; while sexual activities in the relations between men and women, prostitution, homosexuality, and a variety of other matters pertaining to sex are described in detail on the basis of material from the same source.

Although it must be admitted that sensuality in the broader and original sense played a large part in the life of the Greeks, it may seem that Dr. Licht is inclined to attach too much importance to eroticism. He regards it as "the prime cause of old Greek culture and the centre of Hellenic life". It is easy to attach too much weight to their frank admission of certain facts. Dr. Licht is also inclined to misinterpret the reticence of classical studies on these matters. The facts were recognised, at any rate in more recent scholarship, if not treated with the minuteness and particularity of the present study.

A History of Later Greek Literature : from the Death of Alexander in 323 B.c. to the Death of Justinian in 565 A.D By Prof. F. A. Wright. Pp. xi+ 415. (London: George Routledge and Sons, Ltd., 1932.) 18s. net.

THIs most helpful compendium of the later Greek literature seems to us to throw much light on the intellectual atmosphere of the period covered. The Alexandrian school of philosophers and scientific workers, such as Euclid, Aristarchus, Archimedes, Eratosthenes, and Hipparchus, is given all the prominence it deserves. It is, however, the prose writers and poets who interest the author most; and the quotations he gives from their works add to the value of his criticisms.
T. G.

No. 3277, VoL. 130] 